\title{
McCay's hypothesis: undernutrition and longevity
}

\author{
BY EDWARD J. MASORO \\ Department of Physiology, University of Texas Health Science Center, San Antonio, \\ Texas 78284-7756, USA
}

Clive McCay et al. (1935) reported a seminal study which showed that reducing the amount of food of rats starting at or soon after weaning to well below that eaten by ad lib.-fed rats resulted in an increase in the length of life. They hypothesized that this increase in longevity is due to the retardation of growth.

In the ensuing years, the life-extending effect of reducing food intake has been confirmed by many investigators using a variety of rat and mouse strains; for specific references, see the encyclopaedic book on the subject by Weindruch \& Walford (1988). This dietary manipulation is called dietary restriction (DR) by biological gerontologists. The life-extending action of DR is clearly a robust and reproducible phenomenon. However, the hypothesis that retardation of growth is the reason for the life extension is not valid as will be discussed later.

\section{DIETARY RESTRICTION RETARDS AGEING PROCESSES}

The fact that DR increases the maximum length of life in rodent populations was long felt to provide strong evidence that ageing processes are slowed by this dietary manipulation. However, recently Finch et al. (1990) have challenged the validity of using maximum life span of a population as an index of the rate of ageing. They believe that the mortality rate coefficient of the Gompertz analysis is more reliable. Holehan \& Merry (1986) assessed the data from four rat studies with regard to the effect of DR on mortality rate doubling time (MRDT). (MRDT is inversely related to the Gompertz mortality rate coefficient.) They found that the MRDT for the ad lib.-fed rats in these studies ranges from 99 to $104 \mathrm{~d}$ and for the dietary-restricted rats (approximately $60 \%$ of the $a d$ lib. food intake) it ranged from 187 to $210 \mathrm{~d}$. These findings on MRDT provide strong evidence that DR slows the ageing processes.

In addition to its effects on longevity, DR also influences many aspects of the ageing phenotype in what appears to be an anti-ageing fashion. For example, it retards most of the age changes which occur in the physiological processes. It also either delays or prevents most age-associated disease processes. The spectrum of physiological and disease processes affected by DR is extensive and has been summarized in tabular form in a recent review article (Masoro, 1993). To provide some insight into the extent of the effects on disease processes, some of the findings obtained in our laboratory from studies with male F344 rats fed ad lib. or restricted to $60 \%$ of the ad lib. intake are presented. Chronic nephropathy, ultimately resulting in kidney failure, is a common problem with increasing age in the males of this inbred rat strain. At the time of spontaneous death, sixty-eight of 182 ad lib.-fed rats had a severity of kidney lesions sufficient to result in kidney failure while only one of 144 dietary-restricted rats had lesions of that severity (Maeda et al. 1985; Masoro et al. 1989). This finding is even more striking in the light of the fact that the dietary-restricted rats were much older at the time of death than the 
Table 1. Influence of diet on median length of life, age of tenth percentile survivors and maximum length of life of male F344 rats (From Iwasaki et al. (1988) and Masoro et al. (1989))

(Values in parentheses are $95 \%$ confidence intervals; $n 60$ for each dietary group)

\begin{tabular}{|c|c|c|c|c|c|c|}
\hline \multicolumn{4}{|c|}{$\begin{array}{l}\text { Percentage restriction of } \\
\text { dietary components }\end{array}$} & \multirow{2}{*}{$\begin{array}{c}\text { Median } \\
\text { length of life (d) }\end{array}$} & \multirow{2}{*}{$\begin{array}{l}\text { Age of tenth } \\
\text { percentile survivors (d) }\end{array}$} & \multirow{2}{*}{$\begin{array}{c}\text { Maximum } \\
\text { length of life (d) }\end{array}$} \\
\hline Energy & Protein & Fat & Minerals & & & \\
\hline 0 & 0 & 0 & 0 & $730(708-764)$ & $857(819-961)$ & 989 \\
\hline 40 & 40 & 40 & 40 & $936(883-984)$ & $1121(1080-1168)$ & 1275 \\
\hline 40 & 0 & 40 & 40 & $956(906-1028)$ & $1158(1125-1230)$ & 1295 \\
\hline 0 & 0 & 40 & 0 & $764(745-782)$ & $884(833-947)$ & 965 \\
\hline 0 & 0 & 0 & 40 & $763(745-785)$ & $879(863-915)$ & 942 \\
\hline
\end{tabular}

* Reduction of intake below the mean intake of ad lib.-fed rats.

ad lib.-fed animals. Pituitary adenoma and leukaemia are the neoplasms which are major contributors to the death of this rat strain (Shimokawa et al. 1993a). DR greatly decreased the contribution of pituitary adenoma to death, being a major contributor in $15 \%$ of the ad lib.-fed rats and in less than $3 \%$ of the dietary-restricted rats. In contrast, leukaemia was a major contributor to the death of $20 \%$ of the ad lib.-fed rats and $28 \%$ of the dietary-restricted rats. This was an unexpected finding which might be a reflection of the fact that the dietary-restricted rats are much older at death than ad lib.-fed rats. Shimokawa et al. (1993b) assessed the age of onset of leukaemia as well as the age of the deaths to which leukaemia was a contributor and found that DR does delay the age of occurrence (by about $100 \mathrm{~d}$ ) of leukaemia but does not retard the progression of the disease (i.e. time between occurrence and death).

\section{DIETARY FACTOR: REDUCED ENERGY INTAKE}

The question arose as to whether the anti-ageing effect of DR is due to a reduction in energy intake or some other dietary component. This issue has been the subject of studies carried out in many laboratories and the findings have been summarized in a review article (Masoro, 1988). The work carried out in our laboratory with male F344 rats is typical of such studies and the results are presented in summary form in Table 1. Reduction in fat or protein or mineral intake is clearly not responsible for the anti-ageing action of DR in male F344 rats. Based on our studies and those of others, the conclusion to be drawn is that it is the reduction of dietary energy intake and not of a specific dietary component which is responsible for the anti-ageing action of DR.

\section{RETARDATION OF GROWTH HYPOTHESIS}

The hypothesis that DR slows the ageing processes by retarding growth was tested in our laboratory (Yu et al. 1985) and Walford's laboratory (Weindruch \& Walford, 1982). The design of our study involved the use of male F344 rats and a DR protocol in which energy intake was reduced below the ad lib. intake by $40 \%$; the following four dietary groups were studied: group 1, ad lib. fed; group 2, DR starting at 6 weeks of age; group 3, DR 
Table 2. Longevity of male F344 rats undergoing dietary restriction at different periods of life (From Yu et al. (1985))

(Values in parentheses are $95 \%$ confidence intervals; $n 40$ for each dietary group)

\begin{tabular}{|c|c|c|c|c|c|}
\hline \multirow[b]{2}{*}{ Group no. } & \multicolumn{2}{|c|}{ Dietary regimen* } & \multirow[b]{2}{*}{$\begin{array}{l}\text { Median length } \\
\text { of life (d) }\end{array}$} & \multirow{2}{*}{$\begin{array}{c}\text { Age of } \\
\text { tenth percentile } \\
\text { survivors }(d)\end{array}$} & \multirow{2}{*}{$\begin{array}{l}\text { Maximum } \\
\text { length of } \\
\text { life (d) }\end{array}$} \\
\hline & $\begin{array}{l}6 \text { weeks- } \\
6 \text { months }\end{array}$ & $\begin{array}{l}6 \text { months } \\
\text { to death }\end{array}$ & & & \\
\hline 1 & ad lib.-fed & ad lib.-fed & $701(676-734)$ & $822(775-941)$ & 941 \\
\hline 2 & $\begin{array}{c}60 \% \text { of ad lib. } \\
\text { intake }\end{array}$ & $\begin{array}{c}60 \% \text { of ad lib. } \\
\text { intake }\end{array}$ & $1057(1004-1122)$ & $1226(1183-1296)$ & 1296 \\
\hline 3 & $\begin{array}{l}60 \% \text { of ad lib. } \\
\text { intake }\end{array}$ & ad lib.-fed & $808(779-842)$ & $918(857-1040)$ & 1040 \\
\hline 4 & ad lib.-fed & $\begin{array}{c}60 \% \text { of } a d l i b . \\
\text { intake }\end{array}$ & $941(870-1031)$ & $1177(1075-1299)$ & 1299 \\
\hline
\end{tabular}

* Rats in all groups were fed ad lib. from weaning to 6 weeks of age.

from 6 weeks to 6 months of age and ad lib. fed thereafter; group 4, DR starting at 6 months of age. The results of this study are summarized in Table 2. The important findings are that DR only during the rapid growth period (group 3) did not markedly increase the age of the tenth percentile survivors or the maximum length of life and that DR starting at 6 months of age (group 4), i.e. when most growth in this strain is completed, increased the age of the tenth percentile survivors and the maximum length of life as effectively as DR started soon after weaning (group 2). This study strongly indicates that the retardation of growth hypothesis of McCay et al. (1935) is not a valid concept as the reason DR retards ageing processes. The study of Weindruch \& Walford (1982) leads to the same conclusion.

\section{ADIPOSE TISSUE HYPOTHESIS}

Berg \& Simms (1960) proposed that DR retards the ageing processes by reducing body fat content. This view was popular because on logical grounds it is to be expected that DR will reduce body fat content and because of the belief held by many that in humans excess body fat leads to premature death. Indeed, even though the evidence, as will be discussed presently, is strongly against this hypothesis, it still has proponents.

A longitudinal life-span study on body fat content in ad lib.-fed and dietary-restricted male F344 rats was carried out in our laboratory (Bertrand et al. 1980). The absolute fat mass and the percentage body fat content were found to be reduced by DR. The surprising findings, however, were that within the ad lib.-fed group, there was no relationship between longevity and body fat content but within the dietary-restricted group they were positively correlated.

Studies on $o b / o b$ mice and C57BL/6J mice (Harrison et al. 1984) yielded data in accord with our findings. The $a b / o b$ mice ate more food than the $C 57 \mathrm{BL} / 6 \mathrm{~J}$ mice, were much fatter, and had a shorter life span. However, dietary-restricted $o b / o b$ mice were fatter than ad lib. -fed C57BL/6J mice but lived much longer; indeed, they lived as long as the very lean dietary-restricted C57BL/6J mice. 
The findings of both studies strongly indicate that the reduction in body fat by DR does not causally relate to its anti-ageing action. Therefore, the hypothesis of Berg \& Simms (1960) must be rejected.

\section{METABOLIC RATE HYPOTHESIS}

Sacher (1977) proposed that DR retards the ageing processes because it lowers the metabolic rate per unit body mass. This hypothesis was widely believed to have identified the basic mechanism of the anti-ageing action of DR. The reasons that this belief was widely held are: (1) the rate of energy utilization has long been considered a major factor in the ageing processes (Rubner, 1908) and (2) metabolic rate probably correlates positively with reactive oxygen species generation (Harman, 1981). However, assessment of energy intake in our studies with male F344 rats revealed that for most of the life span, the energy intake per unit lean body mass is similar in ad lib.-fed and dietaryrestricted rats (Masoro et al. 1982). The reason for this surprising finding is that DR causes the lean body mass to fall in proportion to the decrease in energy intake (Yu et al. 1982). In the same strain of rat, it was also found that for most of the life span $\mathrm{O}_{2}$ consumption per unit lean body mass is similar in ad lib.-fed and dietary-restricted rats (McCarter \& Palmer, 1992) although upon initiation of DR $\mathrm{O}_{2}$ consumption decreased, gradually returning within a few weeks to the level of the ad lib.-fed rats (McCarter \& McGee, 1989).

A long-term decrease in the intensity of metabolism is clearly not the basis of the anti-ageing action of DR. The conclusion to be drawn from the existing data is that the factor responsible for the anti-ageing action of DR is the intake of energy per animal and not per unit lean body mass.

\section{HYPOTHESES CURRENTLY UNDER INVESTIGATION}

Currently there are three provocative leads to the mechanisms by which DR retards the ageing processes. These leads can be labelled: (1) the glucose-insulin hypothesis; (2) the oxidative damage hypothesis; (3) the general protective action hypothesis.

Glucose-insulin hypothesis. Chronic hyperglycaemia and hyperinsulinaemia are known to be damaging and have been linked to microvascular disease, macrovascular disease, basement-membrane thickening, impaired cellular immunity, cell cycle abnormalities, coronary heart disease, hypertension and atherosclerosis (Ducimetiere et al. 1980; Ferrari \& Weidmann, 1990; Rossetti et al. 1990; Stout, 1990). Normal levels of plasma glucose and insulin acting over the life span, also, may cause damage which may play a causative role in senescence. A longitudinal study on male F344 rats carried out in our laboratory (Masoro et al. 1992) has shown that DR markedly influences the glucose-insulin system. Our findings on the diurnal pattern of plasma glucose concentration reveal that for most of the day the dietary-restricted rats have lower levels than ad lib.-fed rats. The mean 24 h plasma glucose concentration is maintained by DR about $150 \mathrm{mg} / \mathrm{l}$ below that of ad lib.-fed rats. DR maintains plasma insulin levels markedly below (one-third to half) those of ad lib.-fed rats. However, the rate at which glucose is used as fuel per $\mathrm{kg}$ lean body mass is similar for ad lib.-fed and dietary-restricted rats. It must be concluded that DR increases glucose effectiveness and/or insulin sensitivity, as defined by Bergman (1989). By enabling effective use of glucose as a fuel at lower 
Table 3. Effects of dietary restriction (DR) on peak plasma free corticosterone concentrations in male F344 rats (From Sabatino et al. (1991))

(Mean values with their standard errors)

\begin{tabular}{|c|c|c|c|c|}
\hline \multirow{2}{*}{$\begin{array}{l}\text { Age-range } \\
\text { (months) }\end{array}$} & \multirow{2}{*}{$\begin{array}{l}\text { Nutritional } \\
\text { state }\end{array}$} & \multirow{2}{*}{$\begin{array}{l}\text { No. of } \\
\text { rats }\end{array}$} & \multicolumn{2}{|c|}{$\begin{array}{c}\text { Peak } \\
\text { concentration (nM) }\end{array}$} \\
\hline & & & Mean & $\mathrm{SE}$ \\
\hline \multirow[t]{2}{*}{$3-7$} & ad lib. & 21 & $34 \cdot 2$ & $3 \cdot 2$ \\
\hline & DR & 21 & $156 \cdot 1$ & 34.9 \\
\hline \multirow[t]{2}{*}{$9-13$} & ad lib. & 21 & $30 \cdot 4$ & $2 \cdot 5$ \\
\hline & $\mathrm{DR}$ & 21 & $139 \cdot 8$ & $36 \cdot 7$ \\
\hline \multirow[t]{2}{*}{$15-19$} & ad lib. & 21 & $73 \cdot 8$ & $14 \cdot 6$ \\
\hline & DR & 21 & $124 \cdot 8$ & $20 \cdot 5$ \\
\hline \multirow[t]{2}{*}{$21-25$} & ad lib. & 15 & $56 \cdot 5$ & $9 \cdot 3$ \\
\hline & DR & 19 & $251 \cdot 1$ & $45 \cdot 1$ \\
\hline
\end{tabular}

lifetime plasma glucose levels and markedly lower plasma insulin levels, DR may well reduce the long-term damage by these essential substances and in this way slow the ageing processes. However, although plausible, a causal role for the reduction in plasma levels of glucose and insulin in the anti-ageing action of DR remains to be established.

Oxidative damage hypothesis. The metabolism of $\mathrm{O}_{2}$ generates reactive oxygen species such as hydroxyl radicals, superoxide radicals and $\mathrm{H}_{2} \mathrm{O}_{2}$ (Cardenas, 1989). The damaging actions of these reactive oxygen species could be a cause of senescence (Kristal \& Yu, 1994). Studies from several laboratories show that DR attenuates reactive oxygen species production and increases antioxidant defence systems (Yu, 1993). Clearly these effects of DR would be expected to reduce oxidative damage and, thus, potentially be a mechanism by which DR retards ageing processes. However, proof that the action of DR on the reactive oxygen species system at least in part underlies its anti-ageing action is lacking but may emerge with further work in this active research area.

General protective action hypothesis. In addition to retarding the ageing processes, DR protects both young and old mice and rats from the harmful effects of acute stressors. For example, during the $48 \mathrm{~h}$ following the surgical implantation of a jugular cannula, DR markedly decreases the percentage loss in body weight (Masoro, 1994). Another example is the ability of DR to increase the resistance of rats to hyperthermic stress (Heydari et al. 1993). A third example is the attenuation by DR of the inflammatory response of the foot pad of BALB/c mice to the injection of carrageenan (Klebanov et al. 1995). Ageing processes can be viewed as long-term low-intensity stressors and the ability to retard senescence can be considered another example of its ability to protect against stressors.

Our studies on glucocorticoids in ad lib.-fed and dietary-restricted male F344 rats (Sabatino et al. 1991) provided insight into a possible mechanism for the protective action of DR. Dietary-restricted and ad lib.-fed male F344 rats have a similar diurnal pattern of free plasma corticosterone concentration with undetectable levels in the early morning hours and peak levels in the late afternoon. However, they differ in that the peak levels are much higher in dietary-restricted rats than in ad lib.-fed rats (Table 3). 
Too low a concentration of plasma glucocorticoids results in a poor response to stressors, while too high a concentration has toxic effects (Munck et al. 1984). It may be that DR sets plasma glucocorticoids at concentrations which are optimally protective against stressors including ageing processes. This possibility warrants further study.

Another way in which DR may have a broad protective action is through the heat-shock-protein system. This class of proteins protects animals against the adverse effects of various stressors (Lindquist, 1986). The ability of rat hepatocytes to express heat-shock protein 70 is enhanced by DR (Heydari et al. 1993). Of course, whether this effect of heat-shock-protein expression relates to the anti-ageing action of DR remains to be established.

\section{APPLICABILITY TO HUMANS}

Does DR have anti-ageing actions in other mammalian species, including humans? This question cannot be answered at this time because the cost in time and other resources to test this action in species longer lived than rodents is so great that up to now such studies have not been done. However, currently there are on-going studies with dogs and non-human primates; but in the case of the former the results have not yet been published and of the latter a definitive answer is years away.

Whether DR can be used as an intervention in human ageing is often the subject of heated debate. Unfortunately, the available evidence is not adequate to either support or deny its efficacy. Widdowson (1992) expresses concern about possible damaging effects of DR particularly if initiated in children. However, since in rodents DR is quite effective when initiated in adulthood, its effects on children need not be a consideration. Weindruch \& Walford (1988) feel that DR would be effective in humans but they recognize the potential risks and disadvantages.

To my mind, the debate about the potential danger and benefits of DR in humans is moot because few, if any, humans are likely to adhere to such an intervention for long. Rather the importance of DR is as a tool for the study of ageing. Indeed, uncovering the mechanisms underlying its anti-ageing action may well lead to interventions in human ageing which will be more acceptable to people than DR.

\section{REFERENCES}

Berg, B. N. \& Simms, H. S. (1960). Nutrition and longevity in the rat II. Longevity and onset of disease with different levels of intake. Journal of Nutrition 71, 255-263.

Bergman, R. N. (1989). Toward physiological understanding of glucose tolerance, minimal-model approach. Diabetes 38, 1512-1527.

Bertrand, H. A., Lynd, F. T., Masoro, E. J. \& Yu, B. P. (1980). Changes in adipose mass and cellularity through the adult life of rats fed ad libitum or life prolonging restricted diets. Journal of Gerontology 35 , $827-835$.

Cardenas, E. (1989). Biochemistry of oxygen toxicity. Annual Review of Biochemistry 58, 79-110.

Ducimetiere, P., Eschwege, E., Papoz, J. L., Richard, J. C., Claude, J. R. \& Rosselin, G. (1980). Relationship of plasma insulin levels to the incidence of myocardial infarction and coronary heart disease mortality in middle aged population. Diabetologia 19, 205-210.

Ferrari, P. \& Weidman, P. (1990). Insulin, insulin sensitivity and hypertension. Journal of Hypertension 8 , 491-566.

Finch, C. E., Pike, M. C. \& Witten, M. (1990). Slow mortality rate accelerations during aging in some animals approximate that of humans. Science 249, 902-905.

Harman, D. (1981). The aging process. Proceedings of the National Academy of Sciences, USA 78, 7124-7128. 
Harrison, D. E., Archer, J. R. \& Astole, C. M. (1984). Effects of food restriction on aging: Separation of food intakes and adiposity. Proceedings of the National Academy of Sciences, USA 81, 1835-1838.

Heydari, A. R., Wu, B., Takalashi, R. \& Richardson, A. G. (1993). The expression of heat shock protein 70 is altered by age and diet at the level of transcription. Molecular and Cellular Biology 138, 2909-2919.

Holehan, A. M. \& Merry, B. J. (1986). The experimental manipulation of ageing by diet. Biological Reviews 61, 329-368.

Iwasaki, K., Gleiser, C. A., Masoro, E. J., McMahan, C. A., Seo, E. \& Yu, B. P. (1988). Influence of the restriction of individual dietary components on longevity: The fat component and the mineral component. Journal of Gerontology: Biological Sciences 43, B13-B21.

Klebanov, S., Shehab, D., Stavinoha, W. B., Yongman, S. \& Nelson, J. F. (1995). Hyperadrenocorticism, attenuated inflammation, and the life-prolonging action of food restriction in mice. Journal of Gerontology: Biological Sciences 50A, B78-B82.

Kristal, B. S. \& Yu, B. P. (1994). Aging and its modulation by dietary restriction. In Modulation of Aging Processes by Dietary Restriction, pp. 1-35 [B. P. Yu, editor]. Boca Raton, Fl: CRC Press.

Lindquist, S, (1986). The heat shock response. Annual Review of Biochemistry 55, 1151-1191.

McCarter, R. J. \& McGee, J. R. (1989). Transient reduction of metabolic rate by food restriction. American Joumal of Physiology 257, E175-E179.

McCarter, R. J. \& Palmer, J. (1992). Energy metabolism and aging: A lifelong study of Fischer 344 rats. American Journal of Physiology 263, E448-E452.

McCay, C., Crowell, M. \& Maynard, L. (1935). The effect of retarded growth upon the length of life and upon ultimate size. Journal of Nutrition 10, 63-79.

Maeda, H., Gleiser, C. A., Masoro, E. J., Murata, 1., McMahan, C. A. \& Yu, B. P. (1985). Nutritional influences on aging of Fischer 344 rats. II. Pathology. Journal of Gerontology 40, 671-688.

Masoro, E. J. (1988). Food restriction in rodents: An evaluation of its role in the study of aging. Journal of Gerontology: Biological Sciences 43, B59-B64.

Masoro, E. J. (1993). Dietary restriction and aging. Journal of the American Geriatrics Society 41, $994-999$.

Masoro, E. J. (1994). Diet and the aging processes. Clinical Journal of Sport Medicine 4, 262-267.

Masoro, E. J., Iwasaki, K., Gleiser, C. A., McMahan, C. A. \& Seo, E. (1989). Dietary modulation of the progression of nephropathy in aging rats: An evaluation of the importance of protein. American Journal of Clinical Nutrition 49, 1217-1227.

Masoro, E. J., McCarter, R. J., Katz, M. S. \& McMahan, C. A. (1992). Dietary restriction alters characteristics of glucose fuel use. Journal of Gerontology: Biological Sciences 47, B202-B208.

Masoro, E. J., Yu, B. P. \& Bertrand, H. A. (1982). Action of food restriction in delaying aging processes. Proceedings of the National Academy of Sciences, USA 79, 4239-4241.

Munck, A., Guyre, P. M. \& Holbrook, N. J. (1984). Physiological functions of glucocorticoids in stress and their relation to pharmacological actions. Endocrine Reviews 5, 25-44.

Rossetti, L., Giaccari, A. \& DeFronzo, R. A. (1990). Glucose toxicity. Diabetes Care 13, 610-630.

Rubner, M. (1908). Das Problem der Lebensdauer und seine Beziehungen zum Wachstum und Ernährung. Munich: Oldenbourg.

Sabatino, F., Masoro, E. J., McMahan, C. A. \& Kuhn, R. W. (1991). Assessment of the role of the glucocorticoid system in aging processes and in the action of food restriction. Journal of Gerontology: Biological Sciences 46, B171-B179.

Sacher, G. A. (1977). Life table modifications and life prolongation. In Handbook of the Biology of Aging, pp. 582-638 [C. E. Finch and L. Hayflick, editors]. New York: Van Nostrand Reinhold.

Shimokawa, I., Higami, Y., Hubbard, G. B., McMahan, C. A., Masoro, E. J. \& Yu, B. P. (1993a). Diet and the suitability of the male Fischer 344 rat as a model for aging research. Journal of Gerontology: Biological Sciences 48, B27-B32.

Shimokawa, I., Yu, B. P., Higami, Y., Ikeda, T. \& Masoro, E. J. (1993b). Dietary restriction retards onset but not progression of leukemia in male F344 rats. Journal of Gerontology: Biological Sciences 48, B68-B73.

Stout, R. W. (1990). Insulin and atheroma. Diabetes Care 13, 631-654.

Weindruch, R. \& Walford, R. (1982). Dietary restriction in mice beginning at 1 year of age: Effect on life span and spontaneous cancer incidence. Science 215, 1415-1418.

Weindruch, R. \& Walford, R. (1988). The Retardation of Aging and Disease by Dietary Restriction. Springfield, Il: Thomas.

Widdowson, E. M. (1992). Physiological processes of aging: Are there special nutritional requirements for elderly people? Do McCay's findings apply to humans? American Journal of Clinical Nutrition 55, 1246 S-1249S. 
Yu, B. P. (editor) (1993). Oxidative damage by free radicals and lipid peroxidation in aging. In Free Radicals in Aging, pp. 57-88. Boca Raton, Fl: CRC Press.

Yu, B. P., Masoro, E. J. \& McMahan, C. A. (1985). Nutritional infuences on aging of Fischer 344 rats. I. Physical, metabolic, and longevity characteristics. Journal of Gerontology 40, 657-670.

Yu, B. P., Masoro, E. J., Murata, I., Lynd, F. T. \& Bertrand, H. A. (1982). Life span study of SPF Fischer 344 male rats fed ad libitum or restricted diets: Longevity, growth, lean body mass and disease. Journal of Gerontology 37, 130-141. 